Research Article

\title{
Comparative Evaluation of Antibacterial Efficacy of Biological Synthesis of ZnO Nanoparticles Using Fresh Leaf Extract and Fresh Stem-Bark of Carica papaya
}

\author{
Droepenu Eric Kwabena ${ }^{1,3}$, Boon Siong Wee ${ }^{1 \llbracket}$, Chin Suk Fun ${ }^{1}$, Kuan Ying Kok ${ }^{2}$, Zaini Bin \\ Assim $^{1}$, Asare Ebenezer Aquisman ${ }^{1,3}$ \\ ${ }^{1}$ Resource Chemistry Program, Faculty of Resource Science and Technology, 94300, Kota Samarahan, Sarawak, Malaysia. \\ ${ }^{2}$ Malaysian Nuclear Agency, Bangi, Kajang, 43000 Selangor, Malaysia. \\ ${ }^{3}$ Graduate School of Nuclear and Allied Sciences, University of Ghana, AE1, Atomic-Accra, Ghana. \\ Corresponding authors. E-mail: kobladodzie01@yahoo.com; swboon@unimas.my
}

Received: Jul. 15, 2019; Accepted: Aug. 22, 2019; Published: Aug. 22, 2019.

Citation: Droepenu Eric Kwabena, Boon Siong Wee, Chin Suk Fun, Kuan Ying Kok, Zaini Bin Assim, and Asare Ebenezer Aquisman, Comparative Evaluation of Antibacterial Efficacy of Biological Synthesis of ZnO Nanoparticles Using Fresh Leaf Extract and Fresh Stem-Bark of Carica papaya. Nano Biomed. Eng., 2019, II (3): 264-27I.

DOI: 10.5101/nbe.v11i3.p264-271.

\begin{abstract}
The study compared the antibacterial activity of synthesized $\mathrm{ZnO}$ nanoparticles (NPs) from fresh leaf and fresh stem bark aqueous extracts of Carica papaya against five selected microbes: Staphylococcus aureus, (Gram positive (+ve)), Escherichia coli (Gram negative (-ve)), Acinetobacter baumanni (Gram-ve), Exiguobacterium aquaticum (Gram+ve), and Klebsielia pneumonia (Gram + ve). The morphological features of the biosynthesized ZnO NPs were analyzed using transmission electron microscope (TEM) and scanning electron microscope (SEM); the Fourier-transform infrared spectrometer (FTIR) technique was used to observe the surface functional groups. The experimental results indicated that $\mathrm{ZnO}$ NPs were successfully synthesized using modified hydrothermal technique, which showed agglomerated flake-like or petal-like shapes with the organic extract surrounding the formed particles. The average particle size of the synthesized $\mathrm{ZnO}$ nanoparticles determined by SEM ranged between 54-97 nm with the width and length of the petal-like structures been $30 \mathrm{~nm}$ and $62 \mathrm{~nm}$ respectively. The average ZnO NPs from fresh stem bark extract of Carica papaya with higher concentrations (100-1000 ppm) demonstrated a higher antibacterial activity than the fresh leaf extracts. On the other hand, ZnO NPs from fresh leaf extracts of lower concentrations (25-50 ppm) rather showed a suitable result than the fresh stem bark. In general, ZnO NPs showed a positive antibacterial result towards the selected microbes. This shows that, the synthesized ZnO NP can be a substitute to chemical methods.
\end{abstract}

Keywords: ZnO; Carica papaya; Antibacterial; FTIR; SEM

\section{Introduction}

Current development in science and technology has shot nanotechnology into the limelight as a field blending material science, bio-nanoscience, and technology [1] together. The interest in nanoparticles of late is as a result of useful properties these nanoparticles possess. These include their specific catalytic, magnetic, electronic, optical, antibacterial and antimicrobial $[2,3]$ wound healing and anti- 
inflammatory properties [4].

The demerits of the inorganic synthesis of nanoparticles have resulted in the use of extracts from different plant genus, biodegradable polymers (chitosan), bacteria and fungi. These materials serve as both stabilizing and reducing agents in the synthesis of nanoparticles [5].

These biomaterials are preferred to inorganic ones because they are environmentally friendly, economical and easily reproducible [6-8]. Zinc oxide ( $\mathrm{ZnO})$ nanoparticles have very effective antibacterial [9] and antifungal activities at without any harmful effect to soil fertility as compared to the conventional antifungal agents [10].

Carica papaya fresh leaves and stem have been reported for different medicinal effects like antiinflammatory, anti-diabetic and anti-microbial activities and there has been various studies regarding their antimicrobial interactions. According to Tay and Chonk [11], nine bioactive compounds were identified in Carica papaya leaf extract they used in controlling Ganodema boninense in their study. No research regarding the biological synthesis of $\mathrm{ZnO}$ nanoparticles had used fresh leaf extract and fresh stem-bark of Carica papaya. Therefore, this present study employed aqueous extract from fresh Carica papaya leaves and stem bark to synthesize $\mathrm{ZnO}$ nanoparticles in a modified hydrothermal process which would be used on some selected microbes to evaluate its efficacy.

\section{Experimental \\ Preparation of plant extracts}

Leaves and stem bark (fresh) of Carica papaya were cut into pieces and washed in tap and deionized water. A weighed mass of $10.0 \pm 0.1 \mathrm{~g}$ of each material was subjected to 20 minutes' boiling in $100 \mathrm{~mL}$ of deionized water, at $60{ }^{\circ} \mathrm{C}$, until the solution turned to light yellow. The extracts were cooled at room temperature, filtered using Smith filter paper (102 Qualitative $\varnothing 125 \mathrm{~mm}$ ) and stored in Schott bottle for further experiments.

\section{Synthesis of ZnO nanoparticles}

Synthesis of ZnO nanoparticles (NPs) employed a kind of hydrothermal technique proposed by Santhoshkumar et al. [12], with slight modifications. A weighed mass of $9.15 \mathrm{~g}(0.05 \mathrm{~mol})$ of zinc acetate dihydrate $\left.\left[\mathrm{ZnCH}_{3} \mathrm{COO}\right)_{2} \cdot 2 \mathrm{H}_{2} \mathrm{O}\right]$ (Sigma-Aldrich,
India) was dissolved in $50 \mathrm{~mL}$ of deionized water in a $250 \mathrm{~mL}$ Schott bottle and heated under $60{ }^{\circ} \mathrm{C}$ with constant stirring using electric stirring hotplate (Favorit). Also dissolve $2.80 \mathrm{~g}$ (0.05 mol) of potassium hydroxide (KOH) (VWR Amresco, US) in $25 \mathrm{~mL}$ of deionized water in $100 \mathrm{~mL}$ Schott bottle under the same condition as $\mathrm{Zn}\left(\mathrm{CH}_{3} \mathrm{COO}\right)_{2} \cdot 2 \mathrm{H}_{2} \mathrm{O}$. After both solutions dissolved completely, the aqueous $\mathrm{KOH}$ was slowly drained drop wise from a burette into the $\mathrm{Zn}\left(\mathrm{CH}_{3} \mathrm{COO}\right)_{2} \cdot 2 \mathrm{H}_{2} \mathrm{O}$ under $60{ }^{\circ} \mathrm{C}$ with vigorous stirring for $1 \mathrm{~h}$ until white precipitate of zinc oxide was formed. $50 \mathrm{~mL}$ of the plant extract was measured into a burette and drained dropwise into the mixture under constant stirring but now under a temperature of $20{ }^{\circ} \mathrm{C}$ with a magnetic stirrer for $3 \mathrm{~h}$. The mixture was cooled to room temperature to precipitate. The mixture underwent centrifuging at $4000 \mathrm{rpm}$ for $30 \mathrm{~min}$ using Fleta 5 Multi-Purpose Centrifuge and was filtered. The solid zinc oxide precipitate was thoroughly washed and dried under hot air. The sample was then kept in airtight container for characterization.

\section{Characterization of ZnO nanoparticles}

Scanning electron microscopy (SEM) and transmission electron microscopy (TEM) were used to determine the morphology of the synthesized ZnO nanoparticle, while Fourier transform infrared spectroscopy (FTIR) and atomic absorption spectroscopy (AAS) were used to analyze the surface functional groups and the elemental composition of the samples.

\section{Preparation of test samples}

The synthesized $\mathrm{ZnO}$ nanoparticle was tested using disc diffusion method on nutrient agar medium [13]. $1000 \mu \mathrm{g} / \mathrm{mL}$ from the synthesized $\mathrm{ZnO}$ sample was prepared by dissolving a calculated amount of the solid sample in $5 \mathrm{~mL}$ of methanol. Serial diluted concentrations of 10, 50, 100, 250, 500, and 1000 ppm were prepared for the study.

\section{Preparation of bacteria broth}

The interested bacteria available for the activity of the biosynthesized $\mathrm{ZnO}$ nanoparticle were obtained from the stock culture provided by Virology Laboratory, UNIMAS (Universiti Malaysia Sarawak). A weighed mass of $2.60 \mathrm{~g}$ of the dried broth was placed in $200 \mathrm{~mL}$ deionized water to dissolve and sterilize using autoclave at a temperature of $121^{\circ} \mathrm{C}$. The bacterial was sub-cultured in a $10.0 \mathrm{~mL}$ of broth, each in recommended glass vial bottle for $16 \mathrm{~h}$ in an 
incubator with a shaker at normal human temperature (i.e. $37^{\circ} \mathrm{C}$ ) [14]. Turbidity (optical density / OD) of the bacterial broth after $16 \mathrm{~h}$ of incubation was computed by UV Mini Spectrophotometer (model 1240 of Shimadzu brand) at wavelength $575 \mathrm{~nm}$. This was compared to the nutrient broth standard until the desired OD of 0.6-0.9 was obtained.

\section{Plate inoculation}

Biohazard cabinet was used for the inoculation of the bacteria [15]. $1 \mathrm{~mL}$ of the prepared broth was streaked over the entire agar plate surface in four different directions using sterile cotton bud. Before applying the test samples, the agar plate was then left for 5-10 min. A $10 \mu \mathrm{L}$ volume of test extract (Carica papaya $\mathrm{ZnO}$ nanoparticle) of concentrations 10,50 , $100,250,500$ and $1000 \mu \mathrm{g} / \mathrm{mL}$ were each pupated onto the discs (6 mm diameter) and gently pressed onto the agar plate using sterile forceps for $10 \mathrm{~min}$ at room temperature. A disc pupated with methanol and $30 \mu \mathrm{g}$ of tetracycline as standard antibacterial agent were used as negative and positive controls respectively. Each of the test samples were tested in triplicate for the bacterium used. The plate samples were then incubated at a temperature of $37^{\circ} \mathrm{C}$ for $24 \mathrm{~h}$ before the inhibition zone around every sample disc being examined. The inhibition zone was computed in diameter ( $\mathrm{mm}$ ) to show the presence of antibacterial activity for all the samples compared to the positive control.

\section{Instrumental analysis Atomic absorption spectrometry (AAS)}

The content of pure zinc ( $\mathrm{Zn})$ was analysed by Perkin Elmer Atomic Absorption Spectrophotometer (Model Optima 8300 series) using $\mathrm{NO}_{2}$ (nitrous oxide), $\mathrm{C}_{2} \mathrm{H}_{2}$ (acetylene) and compressed air for burning. Standard and blank solutions were prepared using $1 \%(\mathrm{v} / \mathrm{v}) \mathrm{HNO}_{3}$. Three different concentrations were prepared by adding suitable volume of stock standard solution to $50 \mathrm{~mL}$ capacity graduated flask and then top up with distilled water to the mark [16].

\section{Results and Discussions Morphological analysis}

In determining the morphology of the synthesized ZnO particles, SEM and TEM techniques were used for the analysis. The procedure followed during sample preparation for analysis using SEM (SU3500, Hitachi) and TEM (JOEL 1230, Japan) technique was proposed by Droepenu and Asare [17]. From the images of the bio-synthesized $\mathrm{ZnO}$ nanoparticles for fresh leaf and fresh stem back aqueous extracts of Carica papaya (Fig. 1(a)-(d)), flake-like or petal-like shapes were recorded which corresponded to a study by Gopal and Kamila [18]. The average particle size of the two synthesized $\mathrm{ZnO}$ nanoparticles (fresh leaf and stem bark extracts) ranged between 54-97 nm with the width and length of the petal-like structures been $30 \mathrm{~nm}$ and $62 \mathrm{~nm}$ respectively. Although a greater proportion of the particles were agglomerated indicating an even distribution of the plant extract in solution, a few were dispersed. TEM images (Fig 1(c) and (d)) of ZnO NPs were enclosed by a thin layer as organic material from the plant extract which served as a capping agent for stabilizing the particles. Similar structures were reported by Tripathi et al. [19-22].

\section{Fourier transform infrared spectroscopy (FTIR) results}

The surface functional groups involved in the synthesized ZnO NPs were identified using FTIR (Thermo Scientific, Nicolet iS10) spectra, as illustrated in Fig. 2(a) and (b) with spectral peaks simplified in Table 1. Sample preparation procedure was carried out as illustrated by Droepenu and Asare [17]. The spectra showed peak in the range of $400-4000 \mathrm{~cm}^{-1}$.

From the results of the two samples, it could be concluded that constituents in both samples were similar. Slight peak changes were observed in some absorption peaks which might be attributed to the different concentration levels as well as some impurities in the samples during analysis. In previous studies regarding ZnO NPs synthesis, absorption peaks were observed at around $400 \mathrm{~cm}^{-1}$ [23-27].

\section{Antibacterial efficacy}

The effect of Carica papaya $\mathrm{ZnO}$ nanoparticle from the aqueous extracts on Staphylococcus aureus, (Gram positive (+ve)), Escherichia coli (Gram negative (-ve)), Acinetobacter baumanni (Gram -ve), Klebsielia pneumonia (Gram +ve) and Exiguobacterium aquaticum (Gram +ve) are given in Table 2.

Escherichia coli (E. coli) was inhibited by the plant leaf extract and stem bark extract in all the concentration as shown in Table 2, within the diameter range of $0.63 \pm 0.06$ to $1 \pm 0.1 \mathrm{~mm}$ and $0.57 \pm 0.06$ to $1.13 \pm 0.06 \mathrm{~mm}$ respectively. At $25 \mathrm{ppm}$, the stem extract of Carica papaya gave weak inhibition against Escherichia coli as compared with leaf extract. There was higher inhibition rate of stem extract from 50 

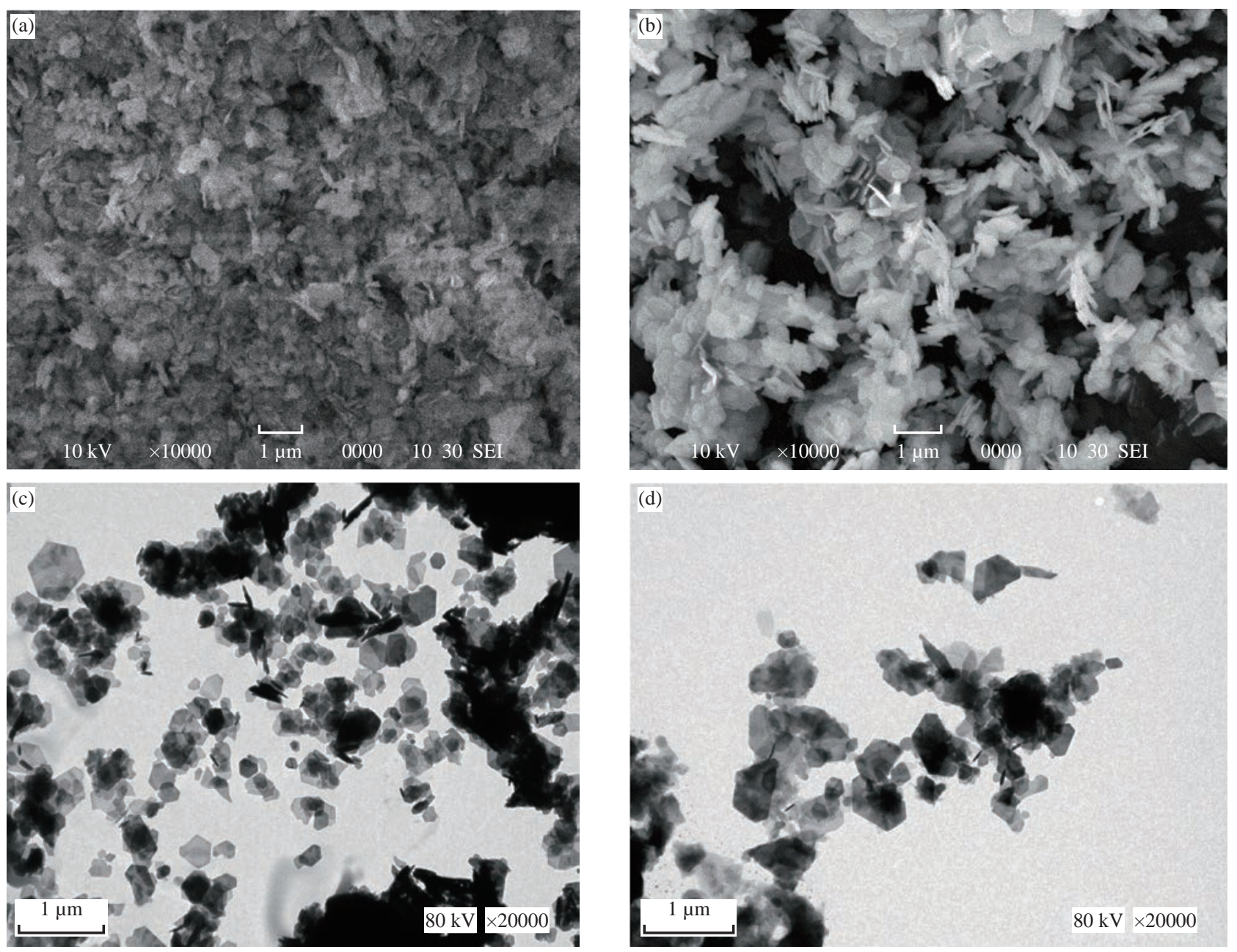

Fig. 1 SEM images of ZnO NPs from (a) fresh leaf and (b) fresh stem bark. TEM images of ZnO NPs from (c) fresh leaf and (d) fresh stem bark aqueous extracts from Carica papaya.

Table 1 FTIR spectral peaks of synthesized ZnO NPs from fresh leaf and stem bark extracts of Carica papaya.

\begin{tabular}{|c|c|c|c|}
\hline Type of extract & Absorption peak $\left(\mathrm{cm}^{-1}\right)$ & Bond / Functional group & Reference \\
\hline \multirow{9}{*}{ Leaf extract } & 441.74 & $\mathrm{Zn}-\mathrm{O}$ & [23]-[27] \\
\hline & 3474.38 & -OH stretching & [12] \\
\hline & \multirow{2}{*}{1629.16} & $\mathrm{C}=\mathrm{O}$ stretching in aromatics & [28] \\
\hline & & $\mathrm{C}=\mathrm{C}$ stretching (alkane) & [12] \\
\hline & 1548.65 & $\mathrm{~N}-\mathrm{H}$ bending in amino acids & [29] \\
\hline & 1400.76 & C-H bending & [12] \\
\hline & 1336.44 & C-N stretching & [28] \\
\hline & 1022.65 & $\mathrm{C}-\mathrm{N}$ stretching & {$[12]$} \\
\hline & 683.76 & C-Alkyl halide & [30] \\
\hline \multirow{9}{*}{ Stem bark extract } & 444.08 & $\mathrm{Zn}-\mathrm{O}$ & [23]-[27] \\
\hline & 3474.61 & -OH stretching & [12] \\
\hline & \multirow[t]{2}{*}{1629.05} & $\mathrm{C}=\mathrm{O}$ stretching in aromatics & [28] \\
\hline & & $\mathrm{C}=\mathrm{C}$ stretching (alkane) & [12] \\
\hline & 1548.69 & $\mathrm{~N}-\mathrm{H}$ bending in amino acids & [29] \\
\hline & 1400.81 & $\mathrm{C}-\mathrm{H}$ bending & [12] \\
\hline & 1338.44 & C-N stretching & [28] \\
\hline & 1019.60 & $\mathrm{C}-\mathrm{N}$ stretching & [12] \\
\hline & 683.59 & C-Alkyl halide & [30] \\
\hline
\end{tabular}

ppm to 1000 ppm against E coli as compared with the inhibition rate of leaf extract. There was strong inhibition rate of stem extract on Escherichia coli at 1000 ppm.
At concentration of 25-1000 ppm in Table 2, the inhibition activity of leaf extracts and stem extracts on the bacteria Staphylococcus aureus, ranged from $0.55 \pm 0.06$ to $0.93 \pm 0.06 \mathrm{~mm}$ and $0.53 \pm 0.006$ to 

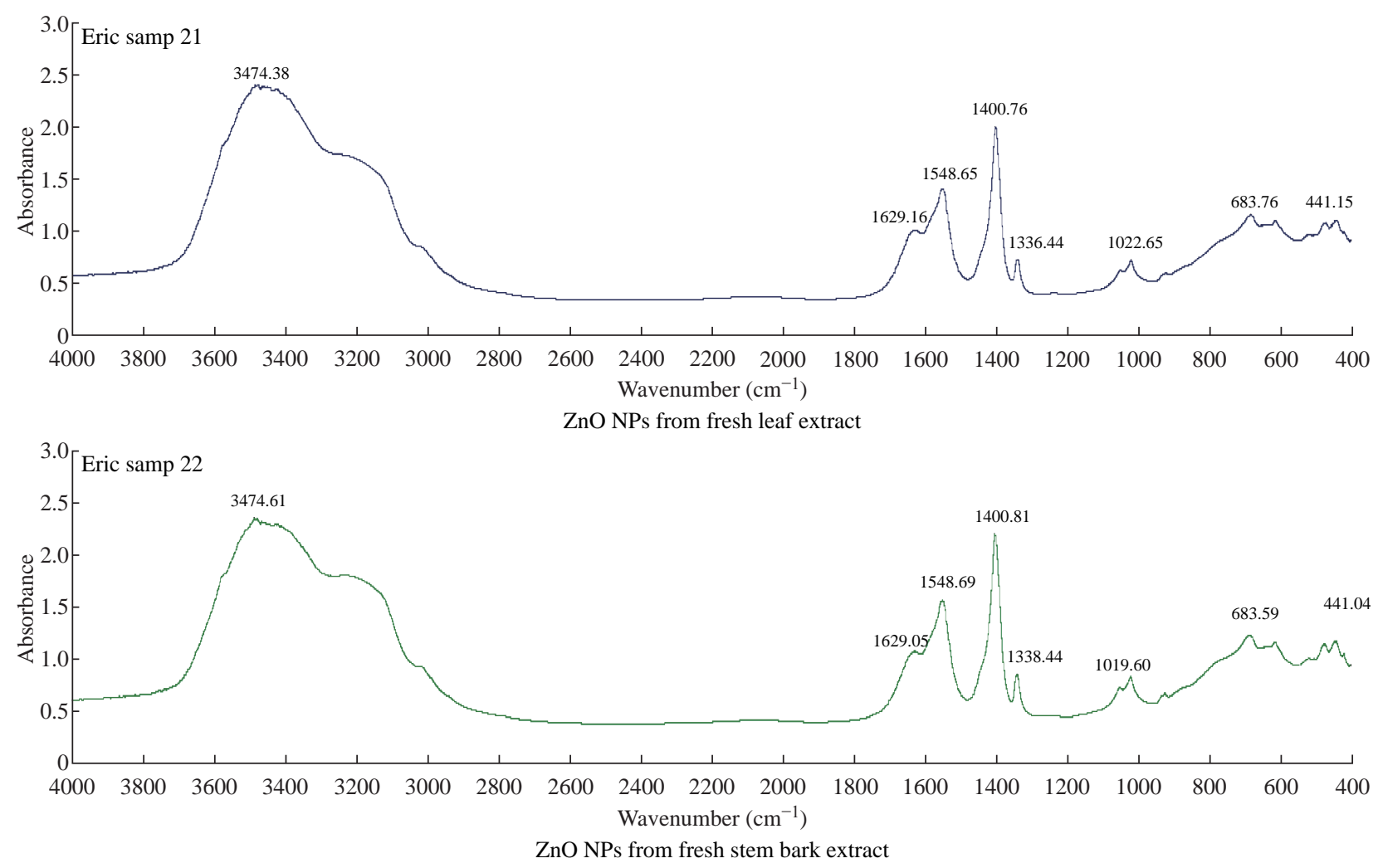

Fig. 2 FTIR spectra of synthesized ZnO NPs using Carica papaya fresh leaf extract and fresh stem-bark extract.

Table 2 Effect of Carica papaya $\mathrm{ZnO}$ nanoparticle from aqueous extracts on selected bacteria

\begin{tabular}{|c|c|c|c|c|c|c|}
\hline \multirow{2}{*}{$\begin{array}{l}\text { Concentration } \\
\quad(\mathrm{ppm})\end{array}$} & \multirow[b]{2}{*}{ Plant part } & \multicolumn{5}{|c|}{ Zone of inhibition (mm) } \\
\hline & & $\begin{array}{l}\text { Escherichia coli } \\
\text { (Gram-ve), }\end{array}$ & $\begin{array}{c}\text { Staphylococcus } \\
\text { aureus (Gram +ve) }\end{array}$ & $\begin{array}{c}\text { Acinetobacter baumanni } \\
\text { (Gram -ve) }\end{array}$ & $\begin{array}{c}\text { Exiguobacterium } \\
\text { aquaticum (Gram +ve) }\end{array}$ & $\begin{array}{c}\text { Klebsielia pneumonia } \\
\text { (Gram +ve })\end{array}$ \\
\hline \multirow{3}{*}{25} & Control & $3.06 \pm 0.01$ & $3.05 \pm 0.06$ & $3.07 \pm 0.02$ & $3.06 \pm 0.01$ & $3.08 \pm 0.03$ \\
\hline & Leaf & $0.63 \pm 0.06$ & $0.55 \pm 0.07$ & $0.87 \pm 0.06$ & $0.67 \pm 0.15$ & $0.87 \pm 0.12^{\mathrm{a}}$ \\
\hline & Stem bark & $0.57 \pm 0.06$ & $0.53 \pm 0.06$ & $0.57 \pm 0.12$ & $0.90 \pm 0.10^{\mathrm{a}}$ & $0.87 \pm 0.06$ \\
\hline \multirow{2}{*}{50} & Leaf & $0.70 \pm 0.00$ & $0.63 \pm 0.15$ & $0.87 \pm 0.06^{\mathbf{a}}$ & $0.67 \pm 0.06$ & $1.00 \pm 0.20^{\mathrm{a}}$ \\
\hline & Stem bark & $0.73 \pm 0.12$ & $0.60 \pm 0.10$ & $0.80 \pm 0.10$ & $0.80 \pm 0.10^{\mathrm{a}}$ & $0.87 \pm 0.12^{\mathrm{a}}$ \\
\hline \multirow{2}{*}{100} & Leaf & $0.73 \pm 0.06$ & $0.67 \pm 0.15$ & $0.83 \pm 0.12^{\mathrm{a}}$ & $0.73 \pm 0.21$ & $0.93 \pm 0.06^{\mathrm{a}}$ \\
\hline & Stem bark & $0.80 \pm 0.10$ & $0.77 \pm 0.06$ & $0.77 \pm 0.06$ & $1.07 \pm 0.06^{\mathrm{a}}$ & $0.97 \pm 0.12$ \\
\hline \multirow{2}{*}{250} & Leaf & $0.83 \pm 0.12$ & $0.93 \pm 0.15^{\mathrm{a}}$ & $0.80 \pm 0.17$ & $0.77 \pm 0.66$ & $0.70 \pm 0.20$ \\
\hline & Stem bark & $0.97 \pm 0.12$ & $0.97 \pm 0.21$ & $0.90 \pm 0.10$ & $1.03 \pm 0.15^{\mathrm{a}}$ & $1.00 \pm 0.20$ \\
\hline \multirow{2}{*}{500} & Leaf & $0.87 \pm 0.23$ & $0.77 \pm 0.12$ & $0.90 \pm 0.10$ & $0.87 \pm 0.15$ & $0.97 \pm 0.06^{\mathrm{a}}$ \\
\hline & Stem bark & $1.03 \pm 0.06$ & $0.83 \pm 0.12$ & $0.90 \pm 0.30$ & $1.17 \pm 0.15^{\mathrm{ab}}$ & $0.97 \pm 0.06$ \\
\hline \multirow{2}{*}{1000} & Leaf & $1.00 \pm 0.10$ & $0.93 \pm 0.06$ & $1.03 \pm 0.12^{\mathrm{ab}}$ & $1.03 \pm 0.06$ & $1.10 \pm 0.10^{\mathrm{b}}$ \\
\hline & Stem bark & $1.13 \pm 0.06^{\mathrm{ab}}$ & $1.07 \pm 0.15^{\mathrm{b}}$ & $0.80 \pm 0.10$ & $1.03 \pm 0.15$ & $1.10 \pm 0.10^{\mathrm{b}}$ \\
\hline
\end{tabular}

Notes: Values are mean \pm standard deviation (SD) for three determinations.

${ }^{\text {a }}$ Significantly $(p<0.05)$ higher compared at the same concentration in each row.

${ }^{\text {b }}$ Significantly $(p<0.05)$ higher compared at the same concentration in each column.

$1.07 \pm 0.015 \mathrm{~mm}$ respectively. High inhibition rate was observed from $50 \mathrm{ppm}$ to $1000 \mathrm{ppm}$ in stem extract than leaf extract unlike at $25 \mathrm{ppm}$. The result showed that the stem-bark of Carica papaya at 1000 ppm has a strong antibacterial activity against Staphylococcus aureus with fairly strong antibacterial activity against Staphylococcus aureus of leaf extract.

Also, Acinetobacter baumanni against leaf and stem 
bark extracts exhibited inhibition within the range of $0.87 \pm 0.06$ to $1.03 \pm 0.12 \mathrm{~mm}$ and $0.57 \pm 0.12$ to 0.80 $\pm 0.010 \mathrm{~mm}$ respectively. There was a considerably high inhibition rate at 25-1000 ppm in leaf extract against Acinetobacter baumanni as compared with stem bark extract. At 1000 ppm, there was a strong antibacterial activity observed in leaf extract against Acinetobacter baumanni unlike stem-bark extract.

The inhibition in relation to leaf and stem-bark extracts against Exiguobacterium aquaticum at 25-1000 ppm were within the range of $0.67 \pm 0.15$ to $1.03 \pm 0.06$ $\mathrm{mm}$ and $0.90 \pm 0.10$ to $1.03 \pm 0.015 \mathrm{~mm}$ respectively. According to Table 2, it was observed there was a fairly high inhibition rate of stem bark extract against Exiguobacterium aquaticum than that of leaf extracts. There was a similarity of inhibition rate of leaf extract and stem bark extract against Exiguobacterium aquaticum at 1000 ppm concentration with some difference in their relative standard deviation.

The activities of the two plants' extract against Klebsielia pneumonia at different concentrations displayed an active inhibition zone from the water leaf and stem bark extract within the range of of $0.87 \pm$ 0.12 to $1.1 \pm 0.06 \mathrm{~mm}$ and $0.87 \pm 0.06$ to $1.1 \pm 0.1 \mathrm{~mm}$ respectively. The inhibition rate at concentration of 1000 ppm was found to have a significant antibacterial activity against Kliebsiela pneumonia in both plants extract.

Fig 3 and 4 represent the inhibition rate of bacteria against each concentration. This is scientifically necessary because it helps to predict the concentration level at which two or more bacteria exhibit the same inhibition rate.

From the studies, it was observed that the antibiotic was found to have the highest antimicrobial activity against all tested microorganism, However, Escherichia coli, staphylococcus aureus and Exiguobacterium aquaticum were more sensitive to water stem bark extract than water leaf extract. The extract from leaf invariably exhibited significant antibacterial activity against Acinetobacter baumanni as compared with stem bark extract. It was observed that the antimicrobial properties of the extracts from leaves and stem-bark of Carica papaya was found

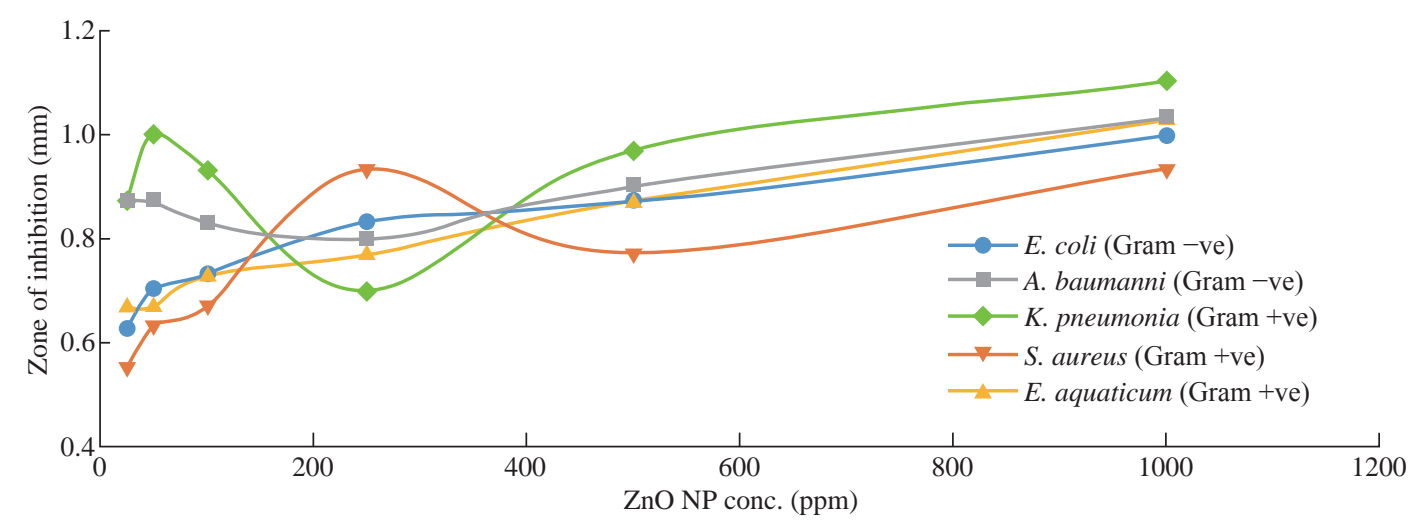

Fig. 3 A graph of inhibition zone against ZnO NPs from fresh leaf extract of Carica papaya.

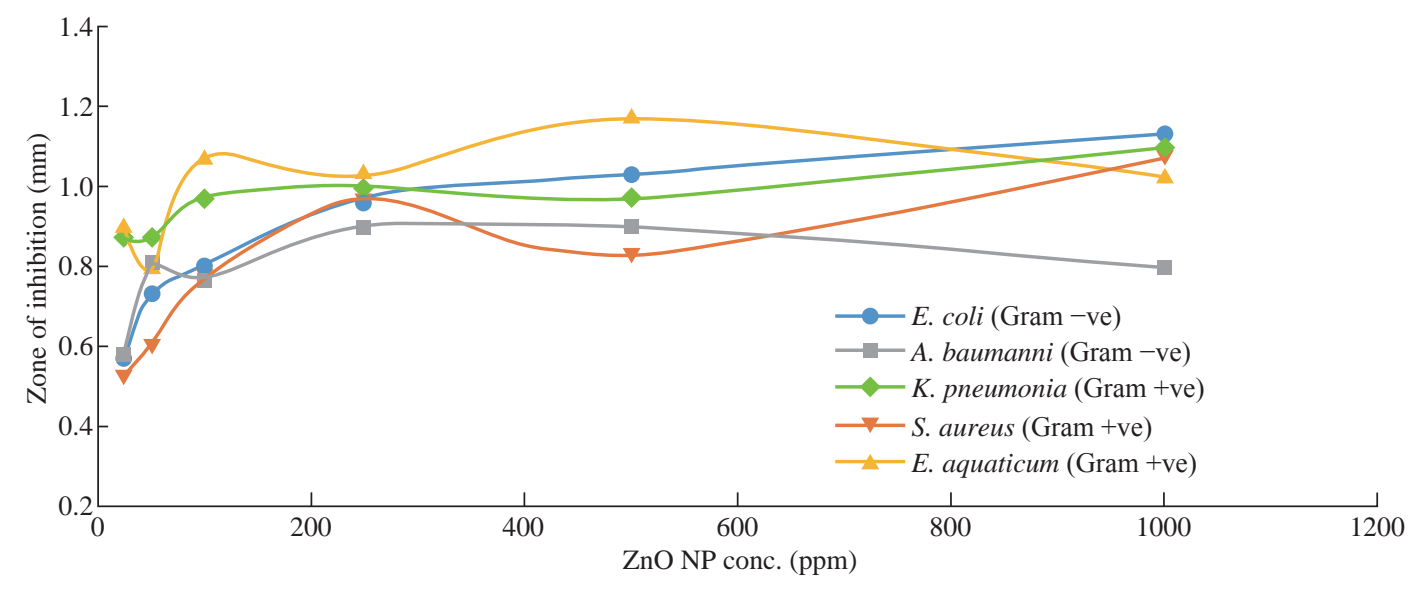

Fig. 4 A graph of inhibition zone against ZnO NPs from fresh stem bark extract of Carica papaya. 
to be dose dependent. Thus, it can be concluded that the traditional use of Carica papaya for the treatment of infectious diseases as suggested by the traditional healers to be promising against bacteria, that is possible because of the presence of some bioactive components which attributed to the microbial activity.

\section{Conclusions}

It is known that the green synthesis of ZnO NPs is much safer and environmentally friendly as compared to chemical synthesis. In response to this assumption, this study successfully used green synthesis to produce ZnO NPs from fresh leaf and fresh stem-bark of Carica papaya aqueous extract. FTIR and AAS confirmed the presence of $\mathrm{ZnO}$ and organic constituents in the fabricated samples. SEM and TEM reported the shape and size of the samples as ranging between 54-97 nm, having agglomerated petal-like morphologies with organic materials from the plant extract surrounding the particles and serving as capping agents. This size synthesized is suitable for applications in the biomedical field foe drug delivery systems. Moreover, the synthesized ZnO NPs exhibited high inhibition activity against Staphylococcus aureus (Gram +ve), Escherichia coli (Gram -ve), Acinetobacter baumanni (Gram -ve), Klebsielia pneumonia (Gram +ve) and Exiguobacterium aquaticum (Gram +ve).

ZnO NPs from fresh stem bark extract of Carica papaya with higher concentrations (100-1000 ppm) demonstrated a higher antibacterial activity than the fresh leaf extracts. On the other hand, $\mathrm{ZnO}$ NPs from fresh leaf extracts of lower concentrations (25-50 ppm) also showed a suitable result than the fresh stem bark. In general, $\mathrm{ZnO}$ NPs showed a positive antibacterial result towards the selected microbes. This shows that the synthesized $\mathrm{ZnO} \mathrm{NP}$ can be an alternative to chemical methods.

\section{Data Availability}

The data used to support the findings of this study are available from the corresponding author upon request.

\section{Acknowledgments}

The authors acknowledge the contribution of colleagues from Faculty of Resource Science and
Technology (FRST) Geochemistry Laboratory and Analytical Laboratory, Universiti Malaysia Sarawak. This research was supported by Universiti Malaysia Sarawak, Tun Openg Chair, with Research Grant Code: F07/TOC/1738/2018.

\section{Conflict of Interests}

The authors declare that they have no conflict of interest.

\section{References}

[1] G. Gnanajobitha, K. Paulkumar, and M. Vanaja, Fruitmediated synthesis of silver nanoparticles using Vitis vinifera and evaluation of their antimicrobial efficacy. Nanostructure Chemistry, 2012, 3(67): 1-6.

[2] N. Duran, P.D. Marcato, and O.L. Alves, Mechanistic aspects of biosynthesis of silver nanoparticles by several Fusarium oxysporum strains. Nanotechnology, 2005, 3: 1-7.

[3] A. Ingle, A. Gade, and S. Pierrat, Mycosynthesis of silver nanoparticles using the fungus Fusarium acuminatum and its activity against some human pathogenic bacteria. Current Nanoscience, 2008, 4: 141-144.

[4] P.L. Taylor, A.L. Usher, and R.E. Burrell, Impact of heat on nanocrystalline silver dressings. Part I: Chemical and biological properties. Biomaterials, 2005, 26: 7221-7229.

[5] S. Ahmed, M. Ahmad, B.L. Swami, et al., A review on plant extracts mediated synthesis of silver nanoparticles for antimicrobial applications: A green expertise. Journal of Advance Research, 2016, 7(1): 17-28.

[6] N. Kulkarni, U.J. Muddapur, Biosynthesis of metal nanoparticles: A review. Nanotechnology, 2014: 1-8.

[7] J. Mittal, A. Batra, A. Singh, et al., Phytofabrication of nanoparticles through plant as nanofactories. Advance Natural Science, Nanoscience Nanotechnology, 2014, 5(4): 043002.

[8] C. Mason, S. Vivekanandhan, M. Misra, et al., Switchgrass (Panicum virgatum) extract mediated green synthesis of silver nanoparticles. World Journal of Nano Science and Engineering, 2012, 2: 47-52.

[9] S. Gunalana, R. Sivaraja, and V. Rajendranb, Green synthesized $\mathrm{ZnO}$ nanoparticles against bacterial and fungal pathogens. Program of Natural Science Material International, 2012, 22(6): 693-700.

[10] K. Feris, C. Otto, and J. Tinker, Synthesis of $\mathrm{ZnO}$ nanoparticles and study of their antibacterial and antifungal properties. Thin Soil Films, 2010, 519: 12241229.

[11] Z.H. Tay, K.P. Chong, (2016). The potential of papaya leaf extract in controlling Ganoderma boninense. IOP Conference Series: Earth and Environmental Science, 2016, 36(1): 012027.

[12] J. Santhoshkumar, S.K. Venkat, and S. Rajeshkumar, Synthesis of zinc oxide nanoparticles using plant leaf extract against urinary tract infection pathogen. ResourceEfficient Technologies, 2017, 3: 459-463.

[13] I.J. Umaru, A.F. Badruddin, and H.A. Umaru, Phytochemical, antifungal and antibacterial potential of Leptadenia hastata stem-bark extract. Toxicology, 2018, 4(4): 263-268.

[14] I.J. Umaru, F.A. Badruddin, Z.B. Assim, et al., Antibacterial and cytotoxic actions of chloroform crude 
extract of Leptadenia hastata(pers)Decnee. Clinical Medical Biochemistry, 2018, 4: 1-4.

[15] I.J. Umaru, F.A. Badruddin, and H.A. Umaru, (2019). Phytochemical screening of essential oils and antibacterial activity and antioxidant properties of Barringtonia asiatica (L) leaf extract. Hindawi Biochemistry Research International, 2019, 2019: Article ID 7143989, 6, 2019.

[16] E.A. Asare, B.A. Zaini, B.W. Rafeah, et al., (2019). Validation of the atomic absorption spectroscopy (AAS) for heavy metal analysis and geochemical exploration of sediment samples from the Sebangan River. Advances in Analytical Chemistry, 2019, 9(2): 23-33.

[17] E.K. Droepenu, E.A. Asare, Morphology of green synthesized $\mathrm{ZnO}$ nanoparticles using low temperature hydrothermal technique from aqueous Carica papaya extract. Nanoscience and Nanotechnology, 2019, 9(1): 29-36.

[18] V.R.V Gopal, S. Kamila, Effect of temperature on the morphology of $\mathrm{ZnO}$ nanoparticles: A comparative study. Applied Nanoscience, 2017, 7: 75-82.

[19] R.M. Tripathi, A.S. Bhadwal, R.K. Gupta, et al., ZnO nanoflowers: novel biobenic synthesis and enhanced photocatalytic activity. J. Photochem. Photobiol. B Biol., 2014, 141: 288-295.

[20] P. Dhandapani, A.S. Siddarth, S. Kamalasekaran, et al., Bio-approach:ureolytic bacteriamediated synthesis of $\mathrm{ZnO}$ Nanocrystals on cotton fabric and evaluation of their antibacterial properties. Carbohydr. Polym., 2014, 103: 448-455.

[21] M.D. Rao, P. Guatam, Synthesis and characterization of ZnO nanoflowers using chlamydomonas reinhardtii: A green approach. Environ. Prog. Sustain. Energy, 2016: 1-7.

[22] S.S. Shankar, A. Rai, A. Ahmad, et al., Rapid synthesis of Au, Ag, and bimetallic Au core-Ag shell nanoparticles using Neem (Azadirachta indica) leaf broth. Journal of Colloid and interface Science, 2004, 275(2): 496-502.

[23] A.K. Zak, R. Razali, W.H. Majid, et al., Synthesis and characterization of a narrow size distribution of zinc oxide nanoparticles. International Journal of Nanomedicine, 2011, 6: 1399-1403.

[24] K. Yang, D. Lin, and B. Xing, Interactions of humic acid with nanosized inorganic oxides. Langmuir, 2009, 25: 3571-3576.

[25] A.B. Lavand, Y.S. Malghe, Synthesis, characterization and visible light photocatalytic activity of nitrogendoped zinc oxide nanospheres. Journal of Asian Ceramic Societies, 2015, 3(3): 305-310.

[26] R.P. Singh, V.K. Shukla, R.S. Yadav, et al., Biological approach of zinc oxide nanoparticles formation and its characterization. Advance Material Letters, 2011, 2(4): 313-317.

[27] C.N.R. Rao, Chemical applications of infrared spectroscopy. Academic Press, New York and London, 1963: 25-40.

[28] K. Vijayalakshmi, D.B. Mahalakshmi, L. Srinivasan, et al., Batch adsorption and desorption studies on the removal of lead (II) from aqueous solution using nanochitosan/sodium alginate/microcrystalline cellulose beads. Int. J. of Bio. Macrom., 2017, 104(Pt B): 14831494.

[29] Y. Zheng, L. Fu, H. Wang, et al., Green biosynthesis and characterization of zinc oxide nanoparticles using Corymbia citriodora leaf extract and their photocatalytic activity. Green Chemistry Letters and Reviews, 2015, 8(2): 59-63.

[30] S. Yedurkar, C. Maurya, and P. Mahanwar, Biosynthesis of zinc oxide nanoparticles using Ixora coccinea leaf extract - a green approach. Open J. Synth. Theory Appl., 2016, 5; 1-14.

Copyright $₫$ Droepenu Eric Kwabena, Boon Siong Wee, Chin Suk Fun, Kuan Ying Kok, Zaini Bin Assim, and Asare Ebenezer Aquisman. This is an open-access article distributed under the terms of the Creative Commons Attribution License, which permits unrestricted use, distribution, and reproduction in any medium, provided the original author and source are credited. 